\title{
Appliance of Public Senior Executives Competences for Municipality Activity Efficiency Development
}

\author{
Martina Blaskova, Ruta Adamoniene, Ruta Petrauskiene
}

\author{
University of Zilina \\ Univerzitna 8215/1, 010 26, Zilina, Slovak Republic \\ E-mail.blaskova@fri.uniza.sk \\ Mykolas Romeris University \\ V. Putvinskio st. 70, LT-44211, Kaunas, Lithuania \\ E-mail.rutadam@mruni.eu
}

Kaunas University of Technology

A. Mickeviciaus st. 37, LT-44244, Kaunas, Lithuania

E-mail.ruta.petrauskiene@ktu.lt

cross $^{\text {ref }}$ http://dx.doi.org/10.5755/j01.ee.28.5.17743

\begin{abstract}
Globalization, economic crisis, political changes, increasing expectations of society and dissatisfaction with policy implemented by the government visibly increase the changes in civil service institutions as well as condition the necessity of strategical thinking and active senior executives in civil service. The performance results of public sector mostly depend on senior executives professionalism, competences in leadership, ability to focus and motivate civil servants so they can achieve set goals. Therefore, one of the most important tasks in every country is to create a professional and competent civil service, which would be able to function effectively in a rapidly changing and complex environment. The necessity of wellprepared and competent public senior executives in present modern institutions is increasing.

There are many classifications of competences in the scientific literature. Summarizing these classifications of competences, the authors distinguish two main groups of competences: common and strategic. The group of common competences, which are required to take a particular position, consists of the following: personal, social, professional and managerial. Meanwhile, the group of strategic competences consists of: cooperation, single-mindedness, possession of vision and leadership. According to respondents' statements it was determined that in the group of common competences (which consists of personal, social, professional and managerial competences) the least demonstrated competence of senior executives of Lithuanian self-government administrations is the managerial one (involves logical, analytical, systemic thinking and so on). In the group of common competences, social competence oriented towards cooperation, partnership, training and development was assessed as the most positive. During the assessment, it was determined that all criteria of strategic competences group (cooperation, single-mindedness, possession of vision and leadership) were assessed by the respondents as important.
\end{abstract}

Keywords: Competence, Competence Model, Common and Strategic Competences, Civil Service, Public Senior Executives.

\section{Introduction}

The environment of public administration became very complicated at the end of the XX century. Firstly, there was a big increase in the extent of authority and this puzzled the work of civil servants. The relations between public and private institutions became complex due to the increased extent of authority. The requirements for public servants competence and skills increased as well. The practice of recent reforms of public administration in different countries shows that a lot of attention is paid to the resultsbased management. It means that this is a management strategy in which all members of a given institution strive to achieve desired results. All these reforms are undertaken in the public sphere and are accompanied by the consideration of the performance efficiency. The importance of efficiency in public administration is conditioned by the fact that public institutions make use of public funds. Therefore, the question of how efficiently these funds are used is especially important to civil servants as well as society.

Performance results of any institution depend on individual knowledge and capabilities, i.e. competence. Competence is described as knowledge, skills and abilities required to perform successful work in a particular position. Using competences, organizations can not only highlight the knowledge, abilities and personal qualities needed for the success in key jobs, but also identify the qualities needed for success across all jobs in the organization (Bounder, Bouchard, Bellemare, 2011, p. 2). Relevant competences are especially important to senior executives` positions. Managerial capacity and competences of individuals, which were important in previous decades, are not as efficient when facing ongoing challenges in external and internal environments of institutions. To react properly to changes, it is important to involve new competences into public sector and focus on senior executives, who would be able to 
creatively and innovatively identify and solve problems, which appear in public sector institutions. The competence of upper-level public servants - the nature and adequacy of their expertise, knowledge, and capacity - is a recurring issue in public administration and a central theme in the ideas of contemporary reformers about enhancing and modernizing state capacity (Hood, Lodge, 2004, p. 313). The ability to cope with uncertainty and change is the question of both attitude and abilities, which require that development of senior executives`competences be focused on change management (Schofield, 2008). A successful public senior executive is someone who is ready to take risks within legislative and political options in order to achieve his/her goals effectively. He/she has to be brave in order to take innovative decisions but at the same time, he/she has to be rational in order to understand the risks, which cannot be taken. Public senior executives' initiatives should be encouraged because, among other important competences, this competence involves sociability and teamwork, which have a direct impact on motivation for changes, willingness to commit and enthusiasm to develop (Schofield, 2008).

While seeking municipality performance efficiency, attention should be paid to development of civil servants' professionalism, which is related to continuing and wellrounded professional improvement as well as the training of capabilities and skills. Knowing the expression of different competences of employees, organizations can invest in their development in very different ways (training programs, coaching trajectories, courses, education trajectories, and so on) (Edelenbos \& van Buuren, 2013, p. 387).

The scientific problem of the article is formulated in the following questions: What is the expression of different groups of competences in the public administration institutions? How are public senior executives prepared for the activity considering constantly ongoing changes?

The object of the research: public senior executives' competences.

This article aims to contribute to the research of competence through an empirical investigation of public senior executives`competences. The purpose of the article - in pursuance of performance efficiency development, to explore the expression of different groups of competences in the municipality administrations of Lithuania.

The paper is organized as follows: the first part of the paper concentrates on a theoretical background of the topic. The second part of the paper is dedicated to the presentation of the survey methodology. The third part of the paper presents the analysis of the survey conducted.

In 2007, as part of the Leonardo da Vinci pilot project „Development of strategic individual competences in the context of European integration ", research was carried out to define strategically relevant individual competences, where 879 respondents from 8 European countries took part. This research pointed out the main strategic competences and their expressions, and the Catalogue of Strategic Individual Competences was formed. The respondents represented the business sector. This article is aimed at adapting the above mentioned research methodology in the public service in order to find out whether these competences and their expression are relevant and specific to the senior executives in public service.
The main two groups of common and strategic competences of public senior executives were distinguished. Group of common competences includes: personal competences (for instance, self-confidence, ability to solve problems decidedly, ability to take decisions independently, etc.), social competences (for instance, chairmanship in the meeting, speaking purposefully, acceptance of various opinions, etc.), professional competences (knowing foreign languages, having a specific career plan, achieving goals, etc.), and managerial competences (generating new ideas, seeking changes, creating long-term goals, etc.). Group of strategic competences includes such competences as foresight and creativity, adaption to new conditions, understanding the need for change, etc.

\section{The Competence Conception, Types and Significance}

The concept of competence is used nowadays widely while talking about human resources in public and private sectors. The performance results depend on individual knowledge and capabilities, i.e. competence. Research and practice related to competences are typically driven by aspirations to achieve a superior performance (on an individual or organizational level) (Fejfarova, Urbancova, 2015 , p. 111). Competence is one of the fundamental factors of organizational capacity. According to Ollila (2013, p. 567), competence is defined as control and practical application of knowledge and skills on demand at work. It is a growing resource whose value increases by using and sharing it. The competence can be described as altogether knowledge, set of capabilities, skills and attitudes, which are necessary for an individual to work effectively in a particular working environment (Savaneviciene, Stukaite, Silingiene, 2008, p. 81). According to Chreptaviciene and Starkute (2010, p. 542), competence (in holistic viewpoint) is specific in the case of every activity.

The concept of competence in scientific literature is analyzed widely enough despite it not having a very deep tradition. Competence research and applications first arrived in 1970, in the quest for understanding the talent of people who are effective (Boyatzis, 2011, p. 91). Pioneers of the research for this are Le Boterf (2010), Boyatzis (1982, 2008), Spencer, Spencer (1993), Collin (1997), Ackerman and Heggestad (1997), Poole, Warner (1998), Schoonover (2011), Weinert (2001). Its concept describes a combination of knowledge, skills and ability to adapt them in particular circumstances. In Lithuania different aspects of competence were analyzed by Lauzackas (2005), Silingiene (2008), Lepaite (2000, 2003), Raudeliuniene (2012), Ruibyte (2013), Pilipavicius (2013), Gudelyte (2015). Competence is not being acquired as traditional qualification by getting diploma; it has to be educated constantly. „Competency comprises the specification of knowledge and skills. The application of knowledge and skills to the standard of performance requires completing a task" (Wu, 2013, p. 259). Therefore, institutions which are striving to correspond to constantly changing requirements have to be oriented towards employees' competences, to create teaching systems which would be consistently oriented towards improving employees' competences. 
Various interpretations of this concept can be summarized like this (Skorkova, 2016, p. 227):

- Competence as an authority and responsibility. An employee is entitled to perform certain activities: Jurisdiction of maneuver and its impact. Therefore, it refers to what has been given to man from the outside.

- Competence as a person's ability to perform a certain activity - quality, skills and ability to do something competently. This notion emphasizes the intrinsic quality of man, which allows him to perform well.

Authors are presenting competence classification on individual level differently: for example, Raudeliuniene, Meidute, Martinaitis (2012) distinguish professional, methodical, social, personal, managerial and inter-cultural competence. According to the authors' statement, professional competence consists of individual's ability to perform few activities and this has a direct relation with his experience, education, qualification. Methodical competence consists of ability to perform work using proper instruments, methods, approaches independently of work's professional content. Social competence extends professional competence and it is understood as individual's inter-personal relations' quality, social skills, ability to strive for goals. Personal competence includes selfmotivation, assessment. Meanwhile managerial competence, which otherwise can be called executive's competence, includes methodical, personal, professional and social competences, is required to take particular position. Inter-cultural competence is individual's acquired ability to work efficiently during interaction of different cultures. According to Lauzackas, Tereseviciene and Stasiunaitiene (2005), qualifications content can be brought under following levels: mono-professional specific competences with narrow activity, group of congenerous competences with medium activity and common competences with wide activity. Meanwhile common competences with wide activity is a group of qualification elements that consists of individual's acquired competences which can be used and adapted in many professions.

For example, managerial competences are a specific type of individual competences; e.g. specific knowledge, abilities, skills, traits, motives, attitudes and values necessary to improve management performance (Fejfarova, Urbancova, 2015, 111 p.).

In opinions of Diskiene and Marcinskas (2007), five groups of competences should be distinguished: strategic, social, functional, managerial and professional, which allow analyzing the archetypal abilities of leaders widely enough. Other scientists distinguish three groups of competences: professional, social and conceptual (Savaneviciene, Stukaite, Silingiene, 2008, p. 81), but also they are talking about the importance of strategic individual competences. Professional competence is very dynamic because of the quickly changing technologies. Social and conceptual competences are general competences, which are necessary for an individual despite his/her position in an organization.

Summarizing classifications of competences presented above and with reference to Leonardo da Vinci pilot project introduced in the abstract, the authors distinguish two main groups of competencies: common and strategic competences. A group of common competences, which are required to take particular position, consists of following competences: personal, social, professional and managerial. They can be used and adapted in many professions. Meanwhile, a group of strategic competences consists of four main senior executives competences which are formulated according to the changes in public management approach (e.g. from ruling to leadership, from avoidance of risk to risk management, from information management to knowledge management, from delegation to empowerment, from individual to team, etc.).

The first one is leadership, which includes inspirational motivation, initiative, empathy, and self-presentation. The leadership in practice means not only the implementation of management functions but also the ability to find necessary means which allow revealing civil servants' possibilities in assuming responsibility. The second group is strategic thinking, which includes having vision, openness to the changes, innovation and decision-making process. The dynamics and unpredictability of environment determine the need to define strategic thinking competences. The third group is purposefulness, which includes targeting, proceeding competence, learning, perfection, and knowledge management. The fourth group is cooperation, which includes teamwork, communication, and conflict management. Ability to cooperate in pursuance of common aims, in providing help for each other, in communicating efficiently, team working skills - are all necessary requirements for leaders. With reference to this classification of competences presented by the authors a questionnaire was prepared and a research conducted. The information about public senior executives` competences in in administrations of municipalities in Lithuania was gathered by applying the method of inquiry. Municipality is an institution closest to citizens and so it has to be able to warranty the main human rights and needs very quickly. Municipality, in striving to conform the needs of citizens, expectations of central power and to be competitive between other municipalities, must plan its activity. In a constantly changing environment such institution of public administration is able to act more efficiently when its activity is oriented towards long-term perspective (Adamoniene, Petrauskiene, 2014, p. 7). The main idea is that a public senior executive should be a very good strategist. A public senior executive can make positive influence on state and local government strategic management in invoking leadership competence and in making more flexible and good result-oriented decisions.

\section{Methodology of the Survey}

The survey of public senior competences was conducted in January - February 2014. An electronic questionnaire consisting of 14 questions was created. First six questions of the questionnaire were related to demographical characteristics of the respondents (age, gender, education, position taken, experience, and represented district). Questions 7-8 revealed who, in respondents' opinion, should assess senior executives' competence and how often it should be done. Questions 9-12 revealed how respondents assess senior executives' common competences (i.e. personal, social, professional and managerial). Questions 
Martina Blaskova, Ruta Adamoniene, Ruta Petrauskiene. Appliance of Public Senior Executives Competences for...

13-14 were intended to identify executives' strategic competences - the frequency of competences appliance and the importance of these competences.

As mentioned earlier, four parts of competences in the common competences` group were distinguished: personal, social, professional and managerial. Each of these into the main criteria was operationalized and every criterion into the particular features was operationalized, which already can be recognized and assessed by respondents. Strategic competences of public senior executives' and their expressions were being researched by using methodology of the pilot research of Leonardo da Vinci project performed in 2007. Four main groups of strategic competences were distinguished (cooperation, single-mindedness, possession of vision and leadership), which were lately operationalized into particular competence features of every group of strategic competences. Logics of research instrument formation is shown in Table 1 .

Table 1

Research Instrument Logics

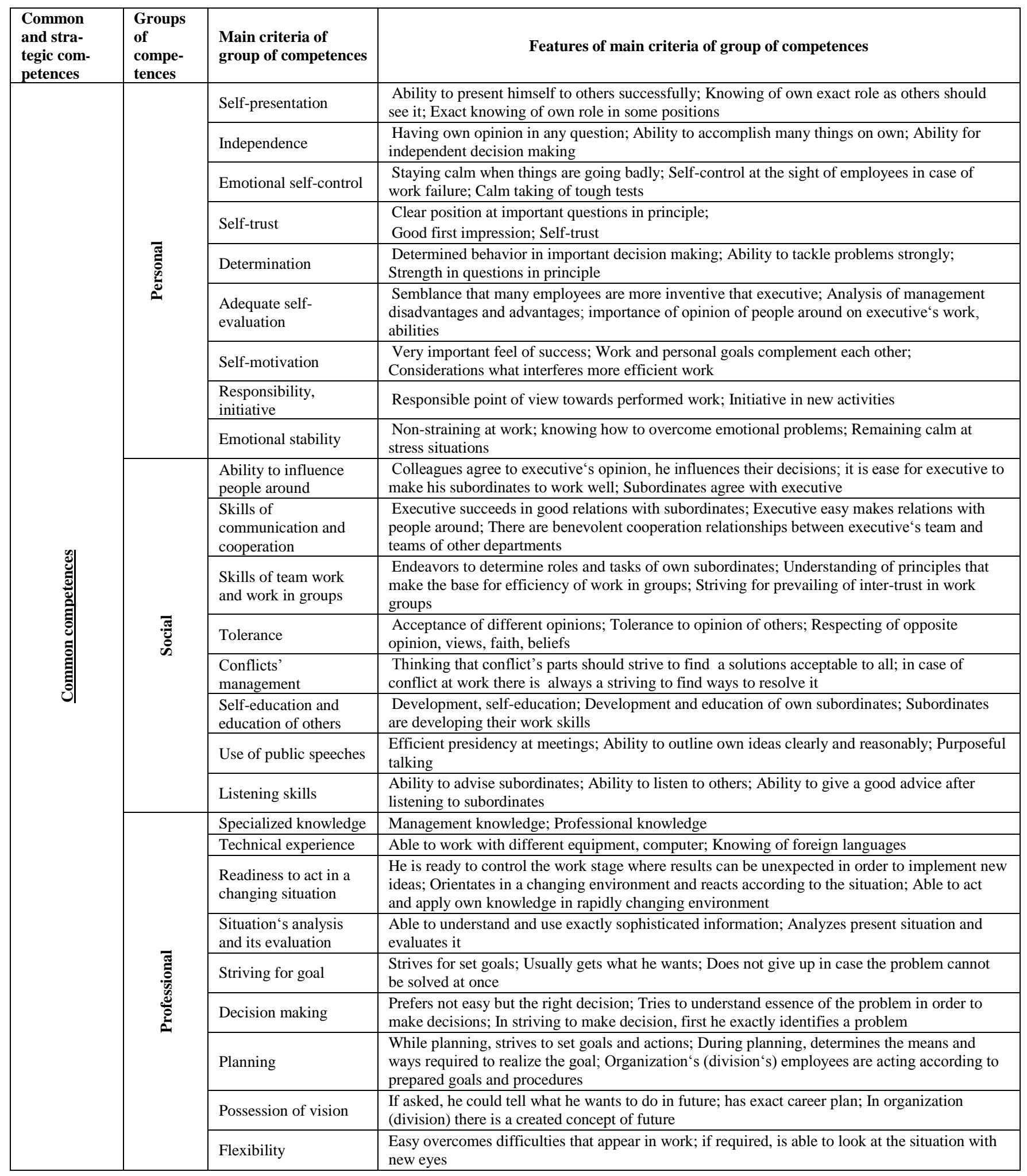




\begin{tabular}{|c|c|c|c|}
\hline & \multirow{8}{*}{ 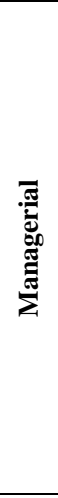 } & Problems' tackling & $\begin{array}{l}\text { Involving of others into the process of problems' tackling; Competence in management of } \\
\text { problems' tackling; Stimulation of subordinates' discussions on management decisions }\end{array}$ \\
\hline & & Management & $\begin{array}{l}\text { Selection of proper management style, efficient management methods; Success in distribution of } \\
\text { positions, empowering; Ability to manage people }\end{array}$ \\
\hline & & Coordination, control & $\begin{array}{l}\text { Efficient work distribution to subordinates; Constant striving in order real activity would } \\
\text { correspond the planned one; Constant monitoring in order the activity would not deviate from } \\
\text { norms determined }\end{array}$ \\
\hline & & Innovativeness & Experimentation in order to implement new ideas; Generating of new ideas; Striving for changes \\
\hline & & $\begin{array}{l}\text { Strategic thinking, } \\
\text { planning }\end{array}$ & $\begin{array}{l}\text { Relating of modern activity to long-term perspective; Creation of long-term plans; Creation of } \\
\text { long-term goals and forethought of long-term means for their implementation }\end{array}$ \\
\hline & & Logical thinking & Constant search for alternative ways; Constant search for more acceptable decisions \\
\hline & & Analytical thinking & Ability to link logically reasons, consequences and events \\
\hline & & Systemic thinking & $\begin{array}{l}\text { Systemic approach to problems' tackling; Understanding of inter-dependence of processes } \\
\text { taking place in the institution; Creation of methods that would help connecting and combining of } \\
\text { processes taking place in the institution }\end{array}$ \\
\hline \multirow{15}{*}{ 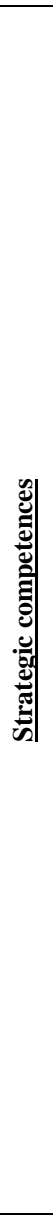 } & \multirow{4}{*}{ 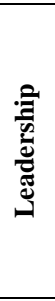 } & Inspiring motivation & $\begin{array}{l}\text { Creates vision of possible achievements, presents goals attractively; Persuades others in success, } \\
\text { enthuses and inspires; Stands as example inspiringly striving for settled goals; Enables others by } \\
\text { giving freedom of actions }\end{array}$ \\
\hline & & Incentive & $\begin{array}{l}\text { Takes for new actions actively; Tells own opinion, ideas; Raises high and ambitious goals for } \\
\text { himself/herself and others; Strives for settled goals hard }\end{array}$ \\
\hline & & Empathy & $\begin{array}{l}\text { Recognizes and understands emotions of other people; Regards emotional state, needs of other } \\
\text { people; Properly expresses emotions }\end{array}$ \\
\hline & & Self-presentation & $\begin{array}{l}\text { Trusts himself/herself; Objectively evaluates own possibilities in particular situation; Creates } \\
\text { strong positive impression; Good speaker }\end{array}$ \\
\hline & \multirow{4}{*}{ 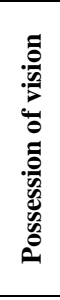 } & Strategic management & $\begin{array}{l}\text { Has clear vision of future; Clearly conveys a vision to others; Clearly describes the main goals; } \\
\text { Follows ethical and moral principles }\end{array}$ \\
\hline & & Openness to changes & $\begin{array}{l}\text { Open to innovations; Understands need for changes; Initiates and implements changes; Adapts } \\
\text { to new conditions }\end{array}$ \\
\hline & & Innovativeness & $\begin{array}{l}\text { Shrewd and creative; Generates and presents new ideas; Experiments, applies new methods of } \\
\text { activity }\end{array}$ \\
\hline & & Decision making & $\begin{array}{l}\text { Identifies and describes problems; Argues and grounds own decision; Presents logical, reasoned, } \\
\text { constructive notes; Envisages alternatives of decision making; Evaluates results and risk of } \\
\text { decisions }\end{array}$ \\
\hline & \multirow{4}{*}{ 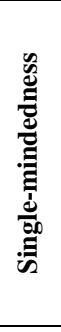 } & Striving for goal & $\begin{array}{l}\text { Is oriented towards long-term goals; Consistently, single-mindedly strives for goals; Strongly } \\
\text { strives for the goal till its implementation }\end{array}$ \\
\hline & & $\begin{array}{l}\text { Procedural } \\
\text { competence }\end{array}$ & $\begin{array}{l}\text { Determines priorities; Plans a course of actions, distributes tasks and resources; Follows } \\
\text { processes and makes required changes; Identifies possible problematic areas and foresees } \\
\text { possibilities of decision }\end{array}$ \\
\hline & & Learning, development & $\begin{array}{l}\text { Notices ideas of others, develops them; Constantly educates own knowledge and abilities; } \\
\text { Constantly develops own personal characteristics; Strives to know more than it is required by } \\
\text { present situation }\end{array}$ \\
\hline & & $\begin{array}{l}\text { Knowledge } \\
\text { management }\end{array}$ & $\begin{array}{l}\text { Intercepts information, knowledge and experience; Shares own information, knowledge and } \\
\text { experience with others; Teaches, advises and supports others, helps to reveal their abilities }\end{array}$ \\
\hline & \multirow{3}{*}{ 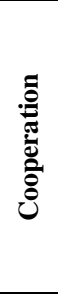 } & Team work & $\begin{array}{l}\text { Help team members; Observes, objectively evaluates and manages processes inside team; } \\
\text { Distributes tasks to team members according to their knowledge, skills, characteristics; Is able to } \\
\text { combine common and individual goals; Summarizes opinion of different team members } \\
\text { (moderates) }\end{array}$ \\
\hline & & Communication & $\begin{array}{l}\text { Clearly expresses own minds, ideas; Presents feedback; Hears others, respects their attitudes and } \\
\text { opinions, customs }\end{array}$ \\
\hline & & Conflict management & $\begin{array}{l}\text { Impartially, objectively behaves in conflict situations; Mediates while tackling a conflict; Is able } \\
\text { to communicate with conflict people; Finds a decision acceptable to conflicting sides } \\
\text { (compromise); Is able to control himself/herself in stress situations }\end{array}$ \\
\hline
\end{tabular}

Cronbach's alpha test was used for reliability of the questionnaire's creation. Table 2 Reliability Statistics presents that the value of Cronbach's alpha coefficient equals 0,9 . Hypotheses $\mathrm{H} 0$ are applied to a whole block of competences.

Table 2

Reliability Statistics

\begin{tabular}{|c|c|}
\hline Cronbach's Alpha & N of Items \\
\hline 0,991 & 93 \\
\hline
\end{tabular}

Verification of hypothesis on the link between age of variables and provision indicates that success in distribution of positions and empowering is an important competence.

We see that $\mathrm{p}$-value of Chi-square criterion according to the Pearson formula as well as to the formula of likelihood ratio is less than the selected level of significance 0,05 . Null hypothesis is rejected. This means that respondents aged 46 and older are more tended to presume that success in distribution of positions and empowering is an important competence. Hence, in this case there is a statistically significant difference between age and provision that success in distribution of positions and empowering is an important competence.

Chi-Square Tests (Significance test)

Table 3

\begin{tabular}{|l|c|c|c|}
\hline & Value & df & Asymp. Sig. (2-sided) \\
\hline Pearson Chi-Square & $41,740^{\mathrm{a}}$ & 28 & 0,036 \\
\hline Likelihood Ratio & 34,173 & 28 & 0,031 \\
\hline $\begin{array}{l}\text { Linear-by-Linear } \\
\text { Association }\end{array}$ & 8,021 & 1 & 0,005 \\
\hline N of Valid Cases & 225 & & \\
\hline
\end{tabular}


Verification of hypothesis on link the between gender of variables and provision indicates that women, unlike men consider examination of management advantages and disadvantages to be an important competence.

We see that p-value of Chi-square criterion according to the Pearson formula as well as to the formula of likelihood ratio is less than the selected level of significance 0,05 .

Null hypothesis is rejected. Therefore, we can state that women, unlike men consider examination of management advantages and disadvantages as an important competence. Hence, in this case there is a statistically significant difference between gender and provision that indicates the examination of management advantages and disadvantages is an important competence.

\section{Chi-Square Tests}

Table 4

\begin{tabular}{|l|c|c|c|}
\hline & Value & df & Asymp. Sig. (2-sided) \\
\hline Pearson Chi-Square & $20,202^{\text {a }}$ & 14 & 0,024 \\
\hline Likelihood Ratio & 20,660 & 14 & 0,011 \\
\hline $\begin{array}{l}\text { Linear-by-Linear } \\
\text { Association }\end{array}$ & 6,116 & 1 & 0,013 \\
\hline N of Valid Cases & 225 & & \\
\hline
\end{tabular}

Respondents' profile. During research of public senior executives` competences, 225 civil servants of Lithuanian municipalities took part, 203 of them filled all questions of their questionnaires properly. Questionnaire surveillance was performed via internet by sending an inquiry to fill the questionnaire and its link by e-mail to civil servants (public senior executives and specialists) of Lithuanian municipalities' administrations. Links were sent to three municipalities of each of the 10 counties (selected randomly). Altogether, the respondents from 29 municipalities participated in the research.

The larger part of respondents $(73.8 \%)$ consisted of women. Age groups of respondents were as follows: 25-35 years $-15,6 \%, 36-45$ years $-18,7 \%, 46-55$ years $-27,1 \%$. $91,1 \%$ of respondents have university education and only a small part of respondents have further education $-3.6 \%$, unfinished higher education - $0,9 \%$ and higher nonuniversity education $-3,1 \%$ of all respondents. Thus, with reference to special requirements to civil servants positions, respondents of high qualification participated in the survey.

The biggest part of respondents $(63,1 \%)$ are civil servants (specialists), 34,7\% of respondents are currently in a senior executive's position, and the rest $2,2 \%$ of respondents are working under a contract of employment. Empirical data was processed by conventional methods of mathematical statistics (using SPSS 12). In order to compare the averages of answers of managers, officials and experts the relative sizes of comparison were applied.

\section{Results of the Survey}

The research was striving to identify and evaluate public senior executives` common and strategic competences.

In order to identify senior executives` common competences in each of the presented parts it was determined how most demonstrated competences of executives are being assessed. Respondents marked a variant corresponding their opinion according to the presented criteria of assessment (from 0 to 5 points) - 0 cannot assess, 1 - this competence was never demonstrated, 2 - this competence was demonstrated rarely, 3 - this competence was demonstrated sometimes, 4 - this competence was often demonstrated, 5 - this competence was always demonstrated, and if the competence is not required to the executive, they marked that in a corresponding column.

Average of senior executives` personal competences assessment is presented in Figure 1.

According to respondents' statement, in the group of senior executives' personal competences the most demonstrated categories are: self-trust (4,54 points), independence (4,46 points), especially in expression of opinion and decision making, self-presentation $(4,44$ points), especially exact knowing of own role at some positions, responsibility (4,38 points), especially in responsible attitude towards performed work.

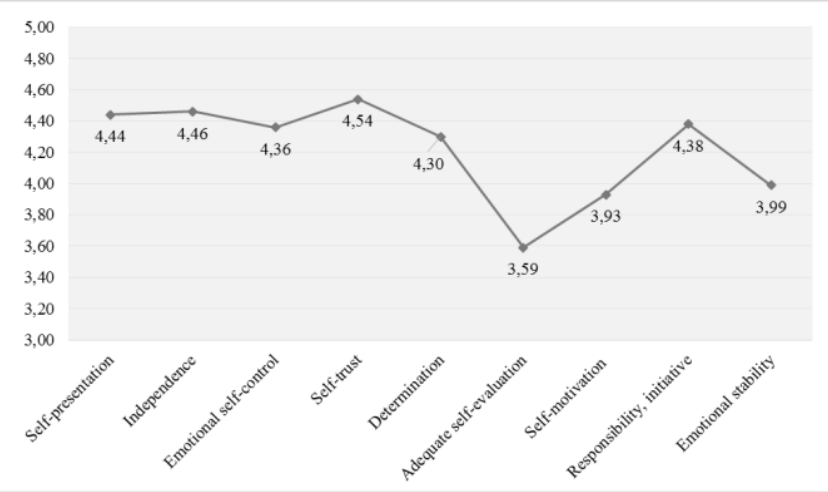

Figure 1. Assessment of senior executives' personal competences (1- this competence was never demonstrated, 5 this competence was always demonstrated), in average points

Least attention was given by respondents to following executive's personal competences demonstrated: adequate self-evaluation (3,59 points), especially examination of management disadvantages, self-motivation (3,93 points), especially considerations about what prevents more efficient work, emotional stability (3,99 points), especially knowing how to overcome emotional problems.

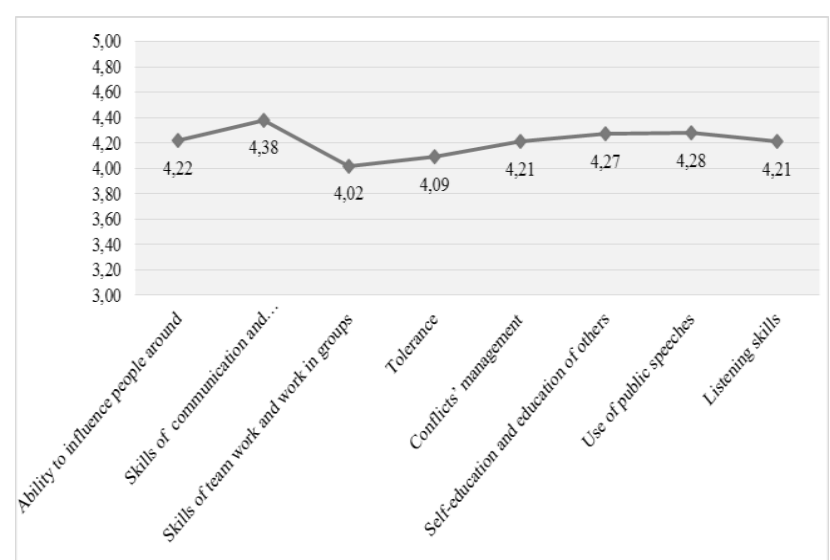

Figure 2. Assessment of senior executives social competences (1- this competence was never demonstrated, 5 this competence was always demonstrated), in average points 
Average of senior executives' social competences assessment presented in Figure 2 did not highlight any clear differences. According to respondents' statements, the most demonstrated executives' competences in the social category are the following: communication and cooperation skills (4,38 points), especially by highlighting good relationship between executive and subordinates, easy establishment of relations with people around, selfeducation and education of others (4,27 points), especially the development of subordinates' work skills, use of public speeches (4,28 points), especially the ability to outline own ideas clearly and reasonably. Respondents gave less attention to the following social competences demonstrated by executives: teamwork and group work skills (4,02 points), especially the understanding of principles that make the base of efficiency of work in groups, tolerance $(4,09$ points), especially the acceptance of different opinions and respect of different beliefs.

Average senior executives` professional competences assessment is presented in Figure 3. According to the respondents' statement, the most demonstrated executives' professional competence categories are the following: specialized knowledge (4.40 points), especially professional knowledge, situation's analysis and its evaluation $(4,14$ points), especially during analysis and evaluation of present situation, striving for goals (4.30 points), especially striving for set goals, decision making (4,14 points), especially striving to understand problem's essence, in decision making. However, respondents gave little attention to the following professional competences demonstrated by the executive: technical experience (3,93 points), especially knowing of foreign languages, possession of vision $(3,74$ points), especially when the concept of organization's future is not clear enough to executive, flexibility ( 3,83 points), especially poor tackling of difficulties at work and noncreative attitude towards situation.

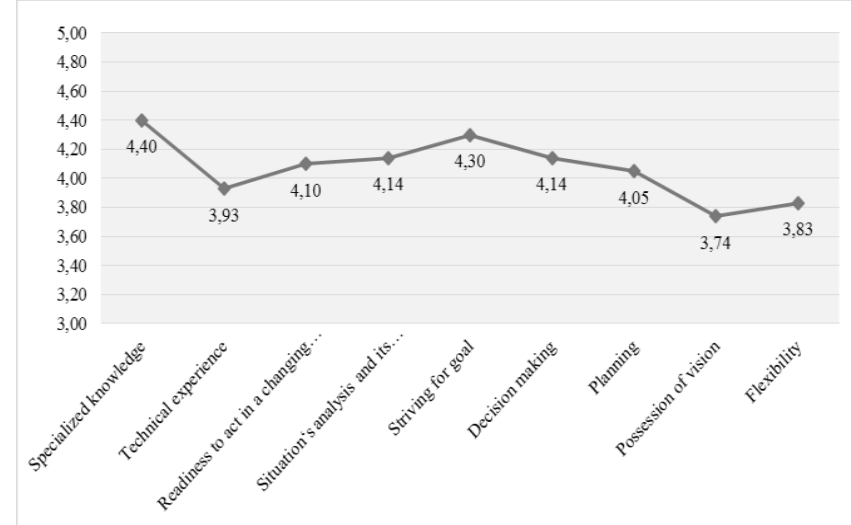

Figure 3. Assessment of senior executives` professional competences (1- this competence was never demonstrated, 5 this competence was always demonstrated), in average points

Average senior executives` managerial competences assessment is presented in Figure 4. According to respondents' statement, the most demonstrated categories of executives" managerial competences are the following: problems ' tackling (3,99 points), especially involving of others into process of problems' tackling, analytical thinking (3,86 points), especially the ability to make logical links between reasons, consequences and events is expressed, management (3,79 points), especially the ability to delegate tasks, coordination, control (3,79 points), especially the constant striving in order for the real activity to correspond with the planned one. However, respondents gave little attention to the following executive's managerial competences demonstrated: innovativeness (3,38 points), especially the experimentation in striving to implement new ideas, strategic thinking, planning (3,60 points), especially the creation of long-term goals, logical thinking (3,62 points), especially the constant search for alternative ways.

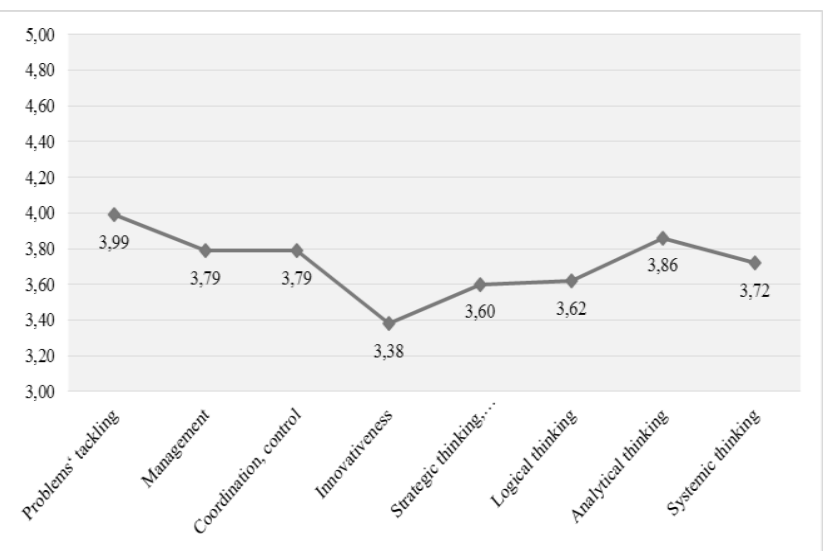

Figure 4. Assessment of senior executives managerial competences ( 1 - this competence was never demonstrated, 5 this competence was always demonstrated), in average points

Analyzing the assessment of common competences (personal, social, professional, managerial) of senior executives and specialists who participated in the research, a sufficient difference between opinions can be noticed. According to data of Figure 5, the competence that requires the most attention and development is managerial competence that includes the most important parts of competences to institutions' senior executives: problem tackling, innovativeness, strategic, logical, analytical, systemic thinking. The most positive assessment in the group of common competences was given to social competence oriented towards cooperation, partnership, education and development.

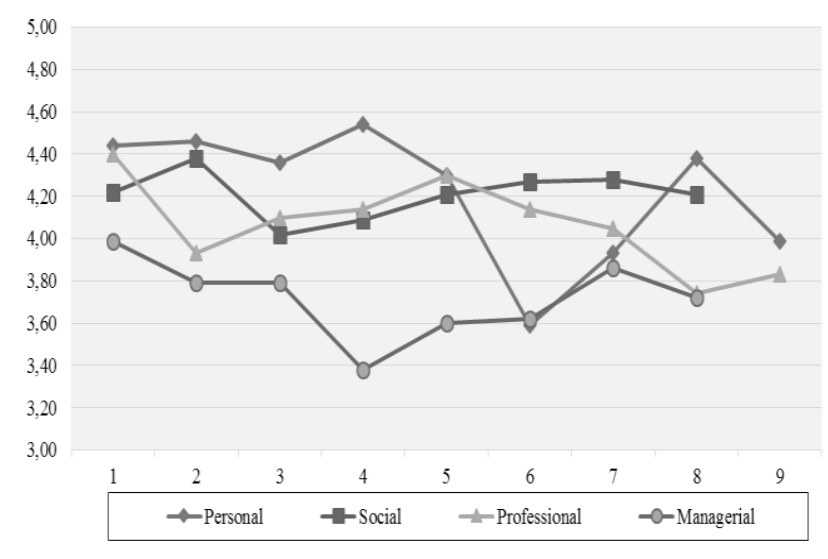

Figure 5. Comparison of obtained results of senior executives`common competences (personal, social, professional, managerial) 
In order to determine, assess and present assumptions and possibilities for development, an assessment of managerial competences should be performed in the institution. Respondents' opinion on who can perform the best mentioned assessment in municipalities was distributed as follows: $28,8 \%$ of respondents think executive should be assessed by his direct executive (if there is such), 29,6\% agree that his employees should assess them too, 28,8\% think the assessment should be done by independent experts' committee, meanwhile the rest of the respondents state that executive should be assessed by colleagues (other executives) (11,7\% of respondents agree with this), and only $1,4 \%$ think that executive should assess himself as well. During assessment of senior executives` competences it is important to set a frequency of this process. In opinion of bigger part of respondents (64,9\%), executives' competence assessment in municipalities should be performed once a year, $28.9 \%$ agree that assessment should be performed more rarely than once a year.

Evaluating the importance of senior executives strategic competences and distinguishing four main groups: cooperation, single-mindedness, possession of vision and leadership, average of evaluations of all criteria in these groups was 3 points, i.e. respondents assessed all presented criteria of competence evaluation as more or less important. None of the presented competences according to 58 criteria was assessed as "absolutely unimportant".

Average evaluations of senior executives` strategic competences according to their importance $(1-$ absolutely unimportant, 4 - very important) and frequency of use (1 never, 4 - constantly) is presented in Figure 6. According to the statements of respondents, five of the most important categories of senior executives' strategic competences (starting from the most important) are distributed as follows: self-presentation (3,51 points), conflict management $(3,45$ points), striving for goals (3,43 points), decision-making $(3,43$ points) and knowledge management (3,42 points).

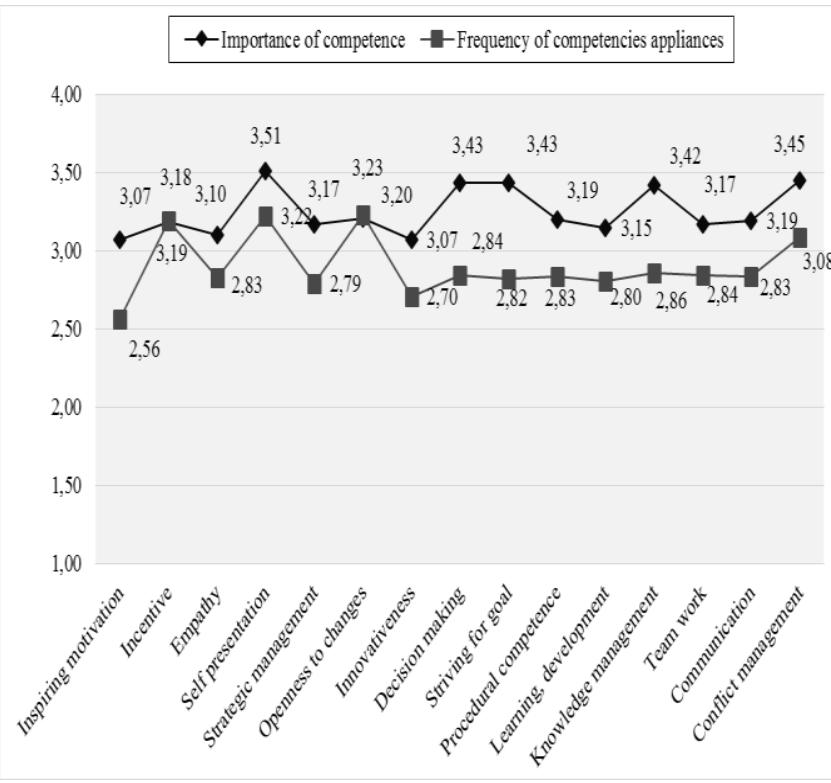

Figure 6. Assessment of senior executives`strategic competences according to importance (1- absolutely unimportant, 4 - very important) and frequency of use (1- never, 4 constantly), in average points
However, the least attention was given by respondents to these senior executives' competences (starting from the least important): inspiring motivation (3,07 points), innovation (3,07 points), empathy (3,1 points), learning and development (3,15 points), possession of vision $(3,17$ points), teamwork (3,17 points), initiative (3,18 points), procedural competence (3,19 points), communication $(3,19$ points) and openness to changes (3,2 points).

According to the research data, during formation of senior executives' strategic competences the following aspects need to be assessed the most: whether leader trusts himself/herself or not, whether he/she tells his/her own opinion and ideas, how the leader is able to control himself/herself in stress situations, if he/she creates a strong positive impression, if the leader strives to achieve a goal until its properly implemented, if he/she intercepts information, knowledge and experience, if the leader clearly expresses his/her minds and ideas, if he/she determines priorities, if he/she presents logical, reasoned, constructive notes, and finally if he/she assesses results and risk of decisions.

Analyzing the biggest gaps between the assessment of respondents' competence importance and frequency of use, following conclusions could be made:

1) very important and frequently used competences: in the field of self-presentation (self-trust and making strong positive impression); in the field of initiative (telling own opinion and ideas);

2) important enough but still rarely used competences: in the field of conflict management (be able to control himself/herself in stress situations), in the field of striving for goals (striving for goals until their proper implementation), in the field of knowledge management (intercepting information, knowledge and experience), in the field of decision making (presenting logical, reasoned, constructive notes and evaluating results and risk of decisions);

3) used frequently enough but not important competences: in the field of openness to changes (adapting to new conditions, understanding need for changes), in the field of conflict management (be able to communicate with conflict people), in the field of vision possession (following ethical and moral principles).

Thus, as shown by the research results the institutions, in order to ensure the appropriate people with the appropriate expertise, are forced to invest more and more into development of staff competences especially into development of public senior executives`competences. But in the meantime it's more of a spontaneous process, covering mainly staff education that suits the institution`s needs which is not enough combined with individual staff goals. At present, a noticeable change in working conditions radically changes the competence-building and training priorities. Therefore, it becomes more and more apparent that priorities are given to the individual's needs. This situation is caused by two main factors:

Firstly, there is a clear change of public governance paradigm. From orientation to institution's past events and their extrapolation with emphasis on risk aversion shifts the situation is changing to organizations operating conditions being associated with future foresight, openness to change, organization flexibility by providing the requirements for 
the competence of the individual, which will lead to future success.

Secondly, competence-building and training priority changes are strongly influenced by the employees themselves, who are more loyal to their careers than the institution that they work for. Therefore, there is a need to define common and strategic individual competences, which would be universal, independent of the activity, and to establish the competence development opportunities at both institutional and individual levels. Only a combination of general and strategic individual competences development at both levels will allow for the optimal result, harmoniously bringing together awareness of the need to raise individual competences and a strong intrinsic motivation to educate themselves and be ready to change.

\section{Conclusions}

The requirements for public senior executives` competence are increasing constantly. Limited resources raised more and more conflicts between public institutions in regards of the use of resources. Especially vigilance of citizens with regard to authority became more intensified. To overcome these challenges in most countries, intensive reforms were started since the beginning of the XXI century. They were based on decreasing management spending, on improvement of efficiency of the public sector and services. Contemporary changes in the public sector are very rapid, therefore, it is essential to be oriented not only towards present day requirements for public senior executives` competence but also it should be foreseen what competences would determine success in the future. Great attention is paid to the development and management of competences in the scientific literature. The competence can be understood as a set of knowledge, capabilities, skills and attitudes, which are necessary for leaders in the rapidly changing environment.

While analyzing a group of common competences it was determined that:

- during formation of executives 'personal competences following aspects should be given most attention and assessed: if executive evaluates employees ' ingenuity, if he analyzes advantages and disadvantages of management, ponders on what prevents him/her to work more efficiently, if he regards opinions of others about executive's work and abilities, how the executive is able to control himself in stressful situations, if he/she is looking for ways on how to overcome emotional problems and stay calm at stressful situations, if strain at work does not disturb rational decision making, if additional goals of work and personal goals are being combined

- during formation of executives' social competences following aspects should be assessed at first: if executive creates endeavors while determining roles and tasks of his subordinates, if he follows principles of work groups ${ }^{6}$ activity efficiency, if he sufficiently strives to gain trust in work groups, if he accepts different opinions and if sufficient tolerance to opinion of others prevails, if self-trust and respect to others' opinions is being felt;

- during formation of executives' professional competences following aspects should be assessed at first: if he has enough abilities to work with different techniques, computer programs, if he strives to improve other technical experience related to knowing foreign languages, if the executive has clear vision of organization's future, if career plans are being formed, if the executive easily overcomes difficulties at work and finally, if he demonstrates flexibly enough an attitude towards differently formed situations;

- during formation of executives " managerial competences following aspects should be assessed at first: if executive is interested to strive for innovativeness in activity, if he tries to experiment, strives to implement new ideas, how executive is able to generate new ideas, if he strives for changes, if executive strives to create long-term plans, goals by thinking and planning strategically, if he applies proper means for their implementation, if he uses logical thinking by constantly searching for alternative ways and more acceptable decisions.

All criteria of strategic competences groups (cooperation, single-mindedness, possession of vision and leadership) were assessed by the respondents as important.

The senior executives and specialists assess strategic competences very similarly: respondents from senior executive's positions think that innovativeness and decisionmaking process are more important competences than conflict management. Although according to specialists, the ability to manage conflict situations is very important in formation of strategic competences of senior executives.

\section{References}

Ackerman, P. L., \& Heggestad, E. D. (1997). Intelligence, personality, and interests: evidence for overlapping traits. Psychological Bulletin, 121, 219-45. https://doi.org/10.1037/0033-2909.121.2.219

Adamoniene, R., \& Petrauskiene, R. (2014). Expression of Strategic Competencies of Leaders in Civil Service: the Case of Municipalities in Lithuania. Human Resources Management \& Ergonomics, 8(2), 6-19.

Bounder, A., Bouchard, C. D., \& Bellemare, G. (2011). Competency-Based Management - An Integrated Approach to Human Resource Management in the Canadian Public Sector. Public Personnel Management, 40(1), 1-10. https://doi.org/10.1177/009102601104000101

Boyatzis, R. E. (1982). The Competent Manager. New York: Wiley.

Boyatzis, R. E. (2002). Core Competencies in Coaching Others. Case Western Reserve University.

Boyatzis, R. E. (2011). Managerial and Leadership Competencies: a Behavioral Approach to Emotional, Social and Cognitive Intelligence. Vision: the Journal of Business Perspective. 15(2), 91-100. Doi: 10.1177/097226291 101500202 
Martina Blaskova, Ruta Adamoniene, Ruta Petrauskiene. Appliance of Public Senior Executives Competences for...

Chreptaviciene, V., \& Starkute, J. (2010). The Model of Cohesions between Career and Competence. Inzinerine EkonomikaEngineering Economics (5), 537-549.

Collin, A. (1997). Learning and Development /I. Beardwell, L. Holden. Human Resource Management: A Contemporary Perspective. London: Pitman.

Diskiene, D., \& Marcinskas, A. (2007). Lietuvos vadybinis potencialas: bukle ir perspektyvos: monografija. Vilnius: Viniaus universiteto leidykla.

Edelenbos, J., \& van Buuren, A. (2013). Organizational Competence Development in Two Public Agencies in the Netherlands: The Effectiveness of In Company Training Versus Learning by Doing. Public Personnel Management. 42(3), 385-402. DOI: 10.1177/0091026013495771.

Fejfarova, M., \& Urbancova, H. (2015). Application of the Competency-Based Approach in Organizations in the Czech Republic. E\&M Economie a Management, 1, XVIII, 111-122. Doi: 10.15240/tul/001/2015-1-009.

Gudelyte, J., \& Adamoniene, R. (2015). Problematic aspects of police officers' competence education. HRM \& E (Human resources management and ergonomics). Zilina: University of Zilina, 9(2), 6-19.

Hood, Ch., \& Lodge, M. (2004). Competency, Bureaucracy, and Public Management Reform: A Comparative Analysis. Governance: An International Journal of Policy, Administration, and Institutions, 17(3), 313-333. https://doi.org/10.1111/j.0952-1895.2004.00248.x

Lauzackas, R., Tereseviciene, M., \& Stasiunaitiene, E. (2005). Kompetenciju vertinimas neformaliajame ir savaiminiame mokymesi. Monografija. Kaunas: VDU leidykla.

Le Boterf, G. (2010). Dar karta apie kompetencija. 15 pasiulymu iprastoms idejoms ispletoti. Klaipeda: KU leidykla.

Lepaite, D. (1998). Kompetencijos vertinimo problema profesinio mokymo procese. Aukstojo mokslo sistemos ir didaktika: konferenciju pranesimu medziaga. Kaunas.

Ollila, S. (2013). Productivity in Public Welfare Services is Changing: The Standpoint of Strategic Competence-Based Management. Social Work in Public Health, 28(6), 566-574. Doi: 10.1080/19371918.2013.791524.

Pilipavicius, V., \& Adamoniene, R. (2013). Influence means fostering competencies of social entrepreneurship. Rural development 2013: the sixth international scientific conference. Akademija : proceedings. Akademija: Aleksandras Stulginskis University, 6(1), 19-24.

Poole, M., \& Warner, M. (Eds.). (1998). The IEBM Handbook of Human Resource Management. London: International Thompson Business Press.

Raudeliuniene, J., Meidute, I., \& Martinaitis, G. (2012). Evaluation System for Factors Affecting Creativity in the Lithuanian Armed Forces. Journal of Business Economics and Management. 13(1), 148-166. https://doi.org/10.3846/1611169 9.2011.639797

Ruibyte, L., \& Adamoniene, R. (2013). Occupational values in Lithuania police organization : managers' and employees' value congruence. Inzinerine Ekonomika-Engineering Economics, 24(5), 22-32. http://dx.doi.org/10.5755/ j01.ee.24.5.3309

Savaneviciene, A., Stukaite, D., \& Silingiene, V. (2008). Development of Strategic Individual Competences. Inzinerine Ekonomika-Engineering Economics(58), 81-88.

Schofield, S. (2008). The Evolution of Government Outsourcing Policy. Contract Management. 48(6), 54-61.

Skorkova, Z. (2016). Competency Models in Public Sector. Procedia - Social and Behavior Sciences, 230, 226-234. Doi: 10.1016/j.sbspro.2016.09.029.

Spencer, L. M., \& Spencer, S. M. (1993). Competence at Work: Models for Superior Performance. New York: John Wiley \& Sons, Inc.

Weinert, F. E. (2001). Concept of Competence: a Conceptual Clarification. In D. S. Rychen \& L. H. Salganik (Eds.), Defining and Selecting Key Competencies (pp. 45-65). Seattle: Hogrefe\&Huber Publishers.

Wu, Jui-Lan. (2013). The Study of CompetencyBased Training and Strategies in the Public Sector: Experience From Taiwan. Public Personnel Management. 42(2), 259-271. Doi: 10.1177/0091026013487124.

The article has been reviewed.

Received in March, 2017; accepted in December, 2017. 